\title{
Geochemical analysis for evaluating the paleoweathering, paleoclimate, and depositional environments of the siliciclastic Miocene-Pliocene sequence at Al-Rehaili area, Northern Jeddah, Saudi Arabia
}

\author{
Faisal Alqahtani ${ }^{1} \cdot$ Mohammed Khali ${ }^{1,2}$
}

Received: 9 April 2020 / Accepted: 13 January 2021 / Published online: 4 February 2021

(C) The Author(s) 2021

\begin{abstract}
Geochemical data and their various approaches are useful to evaluate the climatic control on the depositional environments. This study aims to evaluate the paleoweathering and plaeoclimate condition that have controls on the depositional environments of the Miocene to Pliocene siliciclastic sequence at Al-Rehaili area, north of Jeddah. To achieve this aim, selected sandstone samples were geochemically (major and trace elements analysis) and petrographically examined. The results of these analyses reveal that the examined sandstones were deposited in non-marine (fluvial/alluvial-lacustrine) environments and suffered from weak to intermediate chemical weathering and intense physical induration under semi-arid to semi-humid climatic conditions.
\end{abstract}

Keywords Geochemistry $\cdot$ Paleoweathering $\cdot$ Climate control $\cdot$ Fluvial deposits $\cdot$ Al-Rehaili area

\section{Introduction}

Geochemical analysis with different techniques is very significant in evaluating the paleoweathering and the climatic control on depositional environments (Obasi and Madukwe 2016; Madukwe et al. 2016). To better understand the erosional processes and weathering in the source areas, the mineralogical and chemical compositions of clastic sedimentary rocks are essential to be studied. The lithology, mineral composition, and the chemical weathering of the source areas along with the postdepositional alteration during the diagenesis are the main controlling factors that govern the geochemistry of clastic sedimentary rocks (Johnsson 1993; Armient et al. 1998). In addition,

This paper was selected from the 2nd Conference of the Arabian Journal of Geosciences (CAJG), Tunisia 2019

Responsible Editor: Marina Rabineau

Faisal Alqahtani

falqahtani@kau.edu.sa

1 Department of Petroleum Geology and Sedimentology, Faculty of Earth Science, King Abdulaziz University, Jeddah, Saudi Arabia

2 Department of Geology, Faculty of Science, Assiut University, Assiut, Egypt these factors are generally controlled by the tectonic, base-level fluctuations, climatic changes, and sediment caliber (Álvarez 2005). Therefore, the major and trace elements can be used to identify the climatic control on clastic sediments during deposition and weathering (Barbera et al. 2006).

Several scattered outcrops of the Miocene-Pliocene siliciclastic successions are exposed in the northeastern part of Jeddah at Al-Rehaili area alongside the coastline plain of the Red Sea. The composition of the Red Sea syn-rift clastic sedimentary rocks is controlled mainly by tectonic, sea-level fluctuation, and climate. Although the lithology and depositional environments of these deposits have been studied and determined by Ghandour and ALWashmi (2013) and Alqahtani and Khalil (2015), very few studies have used the geochemical data to evaluate the factors that control the formation and depositions of these deposits using geochemical analysis (Alqahtani and Khalil 2019). Alqahtani and Khalil (2019) used geochemical data to determine the tectonic control on depositing the clastic sedimentary rocks alongside the Red Sea. Similar results are also presented by Ghandour and AL-Washmi (2013). The present study aims to examine the climate control, weathering, and depositional environments of the Miocene Pliocene succession (Bathan Formation) exposed at Al-Rehaili area using geochemical data. 
a
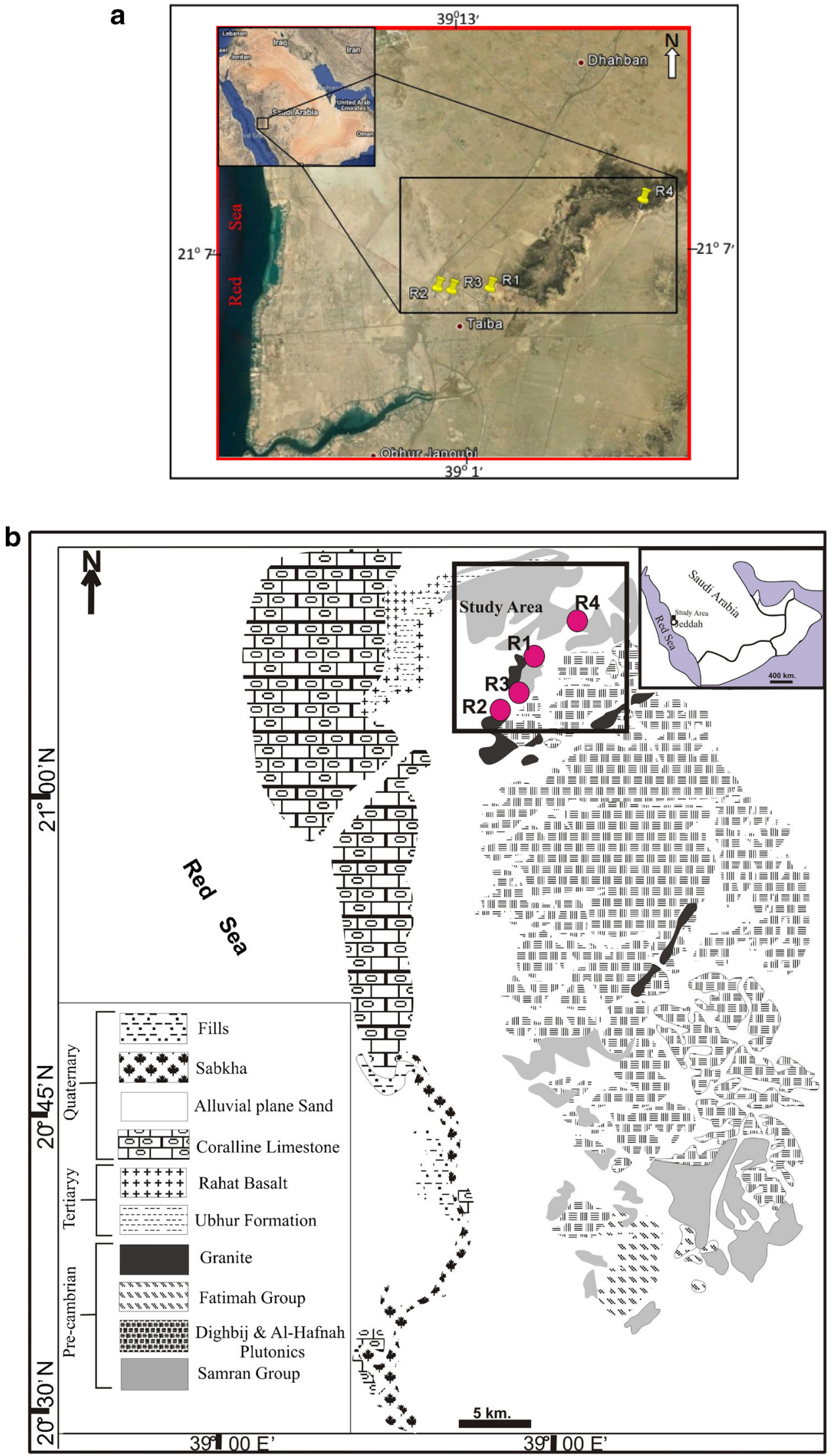

Fig. 1 a A satellite image of Al-Rehaili area (North of Jeddah) displaying the position of the study region and the studied sections. b A geological map of Al-Rehaili area (North of Jeddah) 


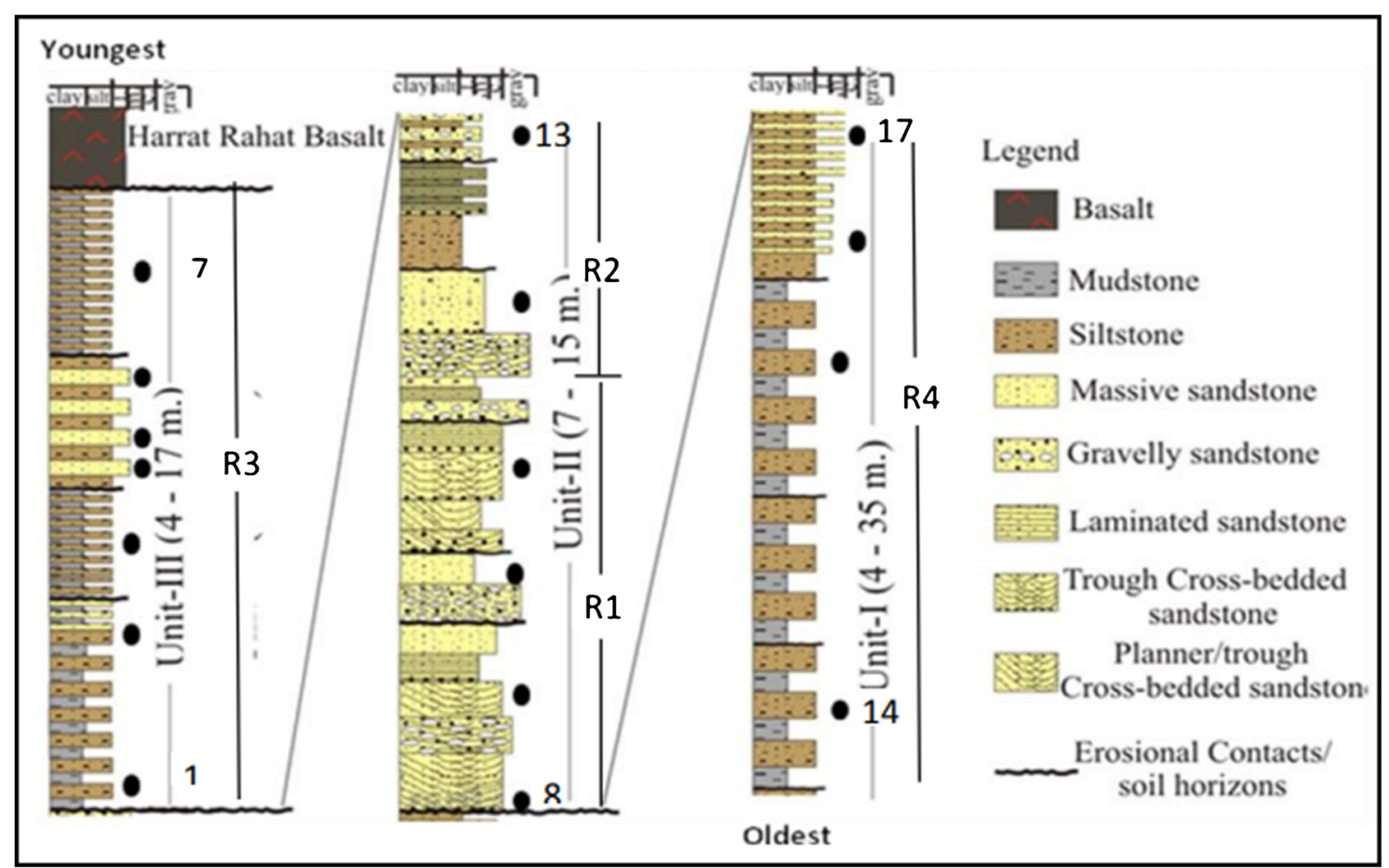

Fig. 2 A measured composite stratigraphic columnar section taken from R1, R2, R3, and R4 (in Fig. 1) showing the sandstone samples (black dots) taken for geochemical analysis (adopted from Alqahtani and Khalil, 2015)

\section{Geological setting}

The study area is situated in Al-Rehaili region, the northeastern part of Jeddah. It lies at latitude of $21^{\circ} 1^{\prime} \mathrm{N}$ and longitude $39^{\circ} 01^{\prime} \mathrm{E}$ (Fig. 1a, b). The Red Sea is interpreted as a young rift system and the sequences within this rift are subdivided into two main subdivision: (1) Pre-rift successions, which are interpreted as continental/fluvial clastic deposits, wherever the oldest deposits are found in Salaman Gulf, a few miles from Jeddah to the north; and (2) syn-rift successions, which are dominated by thick evaporite-siliciclastics sequences (Schmidt and Hadley 1984). The tectonic and structural settings of the Red Sea rift are extensively studied (Townsend et al. 2009; Xu et al. 2012).

The present study concentrates on the Bathan Formation, which is $100 \mathrm{~m}$ thick and contains shale, fine grained, and medium- to coarse-grained sandstones with dispersed pebbles and gravels. It is interpreted to be deposited in non-marine (fluvio-lacustrine) environments (Ghandour and AL-Washmi 2013; Alqahtani and Khalil 2015, 2019). Moreover, the Bathan Formation is believed to be deposited during the major rifting phase, which created horst graben structure. This phase records the first major rapid uplift of the Red Sea escarpment (Ghandour and AL-Washmi 2013). The age of Bathan Formation was difficult to be precisely determined due to the lack of biostratigraphic data. However, the exposed successions are unconformably overlain by basaltic rocks of
Harrat Rahat. These basaltic rocks are believed to be 511 Ma old (Chen et al. 2016; Moufti and Németh 2016). Moreover, Schmidt and Hadley (1984) interpreted equivalent succession alongside the coastal plain of the Red Sea to the north of Jeddah to be 12 to $15 \mathrm{Ma}$ old. Therefore, and based on its stratigraphic situation, the Bathan Formation is interpreted to be deposited during Miocene-Pliocene. In addition, Alqahtani and Khalil (2015) divided the non-marine successions of Bathan Formation into three main sedimentary units (units I, II, and III; Fig. 2). Similar units and deposits are also found and described by Ghandour and AL-Washmi (2013).

\section{Data sources and methodology}

Alqahtani and Khalil (2015) created several stratigraphic composite columnar sections covering four outcrops at AlRehaili area (Fig. 2). These stratigraphic columns were correlated throughout the study area using lateral tracing, soil zones, and the marked erosional surfaces. In addition, the lithology, sedimentary facies, and depositional environments of the main sedimentary units were described and interpreted. Furthermore, Alqahtani and Khalil (2019) collected 17 samples from several sandstone beds and units for geochemical analysis (Figs. 2, 3 and 4). These samples were crushed for $60 \mathrm{~s}$ using Herzog Gyromill (Simatic C7-621). In addition, 2-mm thick pellets 


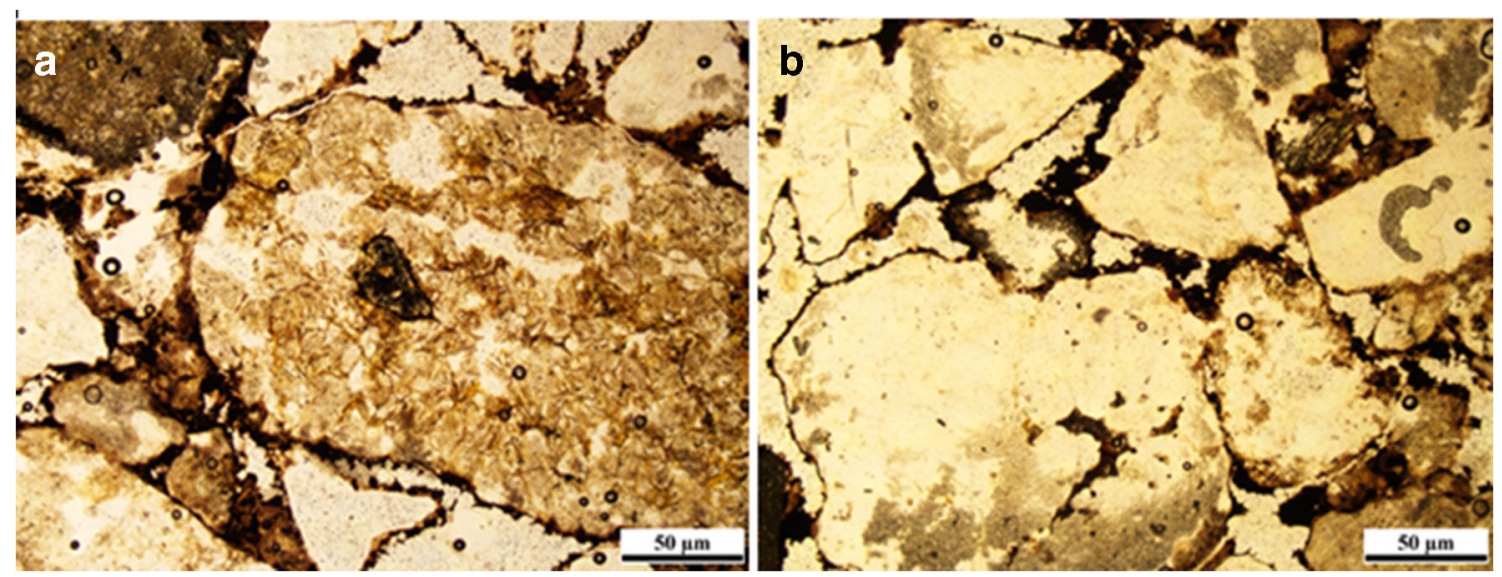

Fig. 3 Medium to coarse-grained pebbly sandstone facies. It is composed of quartz, rock fragments, feldspars inside detrital clay, and iron oxide matrix

were prepared from the pulverized sample by grinding $20 \mathrm{~g}$ of it with $0.4 \mathrm{~g}$ of stearic acid for $60 \mathrm{~s}$ and were loaded into each sample holder of the X-ray machine (Phillips PW1660) for analysis.

Alqahtani and Khalil (2019) determined several major oxide elements such as $\mathrm{SiO}_{2}, \mathrm{Al}_{2} \mathrm{O}_{3}, \mathrm{CaO}, \mathrm{Fe}_{2} \mathrm{O}_{3}, \mathrm{~K}_{2} \mathrm{O}, \mathrm{MgO}, \mathrm{MnO}$, $\mathrm{Na}_{2} \mathrm{O}, \mathrm{P}_{2} \mathrm{O}_{5}, \mathrm{TiO}_{2}$, and $\mathrm{SO}_{3}$ using x-ray fluorescence spectrometry (XRF) and trace elements via ICP-MS (Inductively Coupled Plasma Mass Spectrometry) (Table 1). In addition, thirty-one trace elements including $\mathrm{Ag}, \mathrm{As}, \mathrm{Ba}, \mathrm{Be}, \mathrm{Bi}, \mathrm{Cd}, \mathrm{Ce}, \mathrm{Co}, \mathrm{Cr}$, $\mathrm{Cu}, \mathrm{Ga}, \mathrm{Ge}, \mathrm{Hf}, \mathrm{La}, \mathrm{Li}, \mathrm{Mo}, \mathrm{Nb}, \mathrm{Ni}, \mathrm{Pb}, \mathrm{Rb}, \mathrm{Sb}, \mathrm{Sn}, \mathrm{Sr}, \mathrm{Ta}, \mathrm{Th}, \mathrm{u}$, $\mathrm{V}, \mathrm{W}, \mathrm{Y}, \mathrm{Zn}$, and $\mathrm{Zr}$ were identified (Table 2). In the present work, we used all the data described above to achieve the objective of this study.

\section{Results}

\section{Chemical composition of the examined sandstones}

According to Alqahtani and Khalil (2019), the general chemical composition of the examined sandstones displays wide variances (see Alqahtani and Khalil (2019) for more information; Table 1). These chemical compositions were plotted into several diagrams. The binary plot of $\mathrm{Al} 2 \mathrm{O} 3$ against $\mathrm{TiO} 2$ is usually used to discriminate sandstones from mudstones (Moore 1992). Plotting the examined samples on this plot shows that all samples are sandstone (Fig. 5a). The binary diagram log of $\mathrm{Na}_{2} \mathrm{O} / \mathrm{K}_{2} \mathrm{O}$ versus $\log \mathrm{SiO}_{2} / \mathrm{Al}_{2} \mathrm{O}_{3}$ which was used and developed by Pettijohn et al. (1987) and Madukwe
Table 1 The percentages of major oxides in the studied samples

\begin{tabular}{|c|c|c|c|c|c|c|c|c|c|c|c|}
\hline S. No. & $\begin{array}{l}\mathrm{SiO}_{2} \\
0.25 \\
\%\end{array}$ & $\begin{array}{l}\mathrm{Al}_{2} \mathrm{O}_{3} \\
0.05 \\
\%\end{array}$ & $\begin{array}{l}\mathrm{CaO} \\
0.05 \\
\%\end{array}$ & $\begin{array}{l}\mathrm{Fe}_{2} \mathrm{O}_{3} \\
0.05 \\
\%\end{array}$ & $\begin{array}{l}\mathrm{K}_{2} \mathrm{O} \\
0.05 \\
\%\end{array}$ & $\begin{array}{l}\mathrm{MgO} \\
0.05 \\
\%\end{array}$ & $\begin{array}{l}\mathrm{MnO} \\
0.05 \\
\%\end{array}$ & $\begin{array}{l}\mathrm{Na}_{2} \mathrm{O} \\
0.05 \\
\%\end{array}$ & $\begin{array}{l}\mathrm{P}_{2} \mathrm{O}_{5} \\
0.05 \\
\%\end{array}$ & $\begin{array}{l}\mathrm{TiO}_{2} \\
0.05 \\
\%\end{array}$ & $\begin{array}{l}\mathrm{SO}_{3} \\
0.05 \\
\%\end{array}$ \\
\hline 1 & 64.4 & 12.90 & 1.22 & 5.34 & 1.58 & 2.20 & 0.14 & 1.29 & 0.16 & 0.48 & $<0.05$ \\
\hline 2 & 74.2 & 10.60 & 2.58 & 3.60 & 1.03 & 1.14 & 0.16 & 1.58 & 0.09 & 0.43 & $<0.05$ \\
\hline 3 & 75.1 & 9.87 & 1.91 & 4.06 & 0.76 & 1.30 & $<0.05$ & 1.83 & $<0.05$ & 0.43 & $<0.05$ \\
\hline 4 & 74.5 & 10.17 & 1.87 & 3.25 & 1.06 & 1.40 & 0.16 & 1.40 & 0.06 & 0.34 & $<0.05$ \\
\hline 5 & 76.2 & 8.73 & 1.26 & 3.44 & 0.98 & 1.49 & 0.05 & 0.89 & $<0.05$ & 0.38 & $<0.05$ \\
\hline 6 & 74.7 & 9.54 & 1.16 & 2.58 & 1.07 & 1.91 & $<0.05$ & 1.26 & 0.05 & 0.30 & $<0.05$ \\
\hline 7 & 71.0 & 11.86 & 2.07 & 4.56 & 1.33 & 1.53 & 0.05 & 1.56 & 0.06 & 0.66 & $<0.05$ \\
\hline 8 & 55.3 & 15.65 & 2.41 & 7.84 & 0.66 & 2.80 & 0.12 & 0.98 & 0.16 & 0.85 & $<0.05$ \\
\hline 9 & 65.0 & 12.82 & 1.92 & 5.80 & 0.78 & 2.28 & 0.09 & 1.63 & 0.06 & 0.69 & $<0.05$ \\
\hline 10 & 61.0 & 8.83 & 5.70 & 3.73 & 0.90 & 4.46 & 0.14 & 0.85 & $<0.05$ & 0.42 & $<0.05$ \\
\hline 11 & 78.8 & 7.25 & 1.28 & 3.20 & 0.57 & 1.08 & $<0.05$ & 1.28 & $<0.05$ & 0.39 & $<0.05$ \\
\hline 12 & 73.7 & 10.76 & 2.90 & 4.19 & 0.76 & 1.16 & 0.08 & 1.73 & $<0.05$ & 0.30 & $<0.05$ \\
\hline 13 & 52.8 & 13.48 & 8.14 & 8.89 & 0.36 & 1.63 & 0.08 & 1.33 & 0.11 & 1.06 & $<0.05$ \\
\hline 14 & 56.6 & 11.39 & 5.56 & 4.25 & 1.00 & 4.74 & 0.07 & 1.01 & 0.08 & 0.48 & $<0.05$ \\
\hline 15 & 68.4 & 12.63 & 1.44 & 4.82 & 1.54 & 1.68 & $<0.05$ & 1.42 & $<0.05$ & 0.53 & $<0.05$ \\
\hline 16 & 72.4 & 11.52 & 1.92 & 3.70 & 1.37 & 1.45 & $<0.05$ & 1.71 & 0.06 & 0.44 & $<0.05$ \\
\hline 17 & 72.13 & 10.91 & 1.77 & 3.65 & 1.32 & 1.54 & 0.05 & 1.69 & 0.06 & 0.44 & $<0.05$ \\
\hline
\end{tabular}


Table 2 The proportions of trace elements in the studied samples

\begin{tabular}{|c|c|c|c|c|c|c|c|c|c|c|c|}
\hline \multirow[t]{3}{*}{ S. No. } & \multirow[t]{3}{*}{ L.O.I $\left(1000^{\circ} \mathrm{C}\right) \%$} & $\mathrm{Ag}$ & As & $\mathrm{Ba}$ & $\mathrm{Be}$ & $\mathrm{Bi}$ & $\mathrm{Cd}$ & $\mathrm{Ce}$ & Co & $\mathrm{Cr}$ & $\mathrm{Cu}$ \\
\hline & & 1.00 & 5.50 & 1.00 & 1.00 & 10.00 & 0.50 & 5.50 & 1.00 & 1.00 & 1.00 \\
\hline & & ppm & ppm & ppm & ppm & ppm & ppm & ppm & ppm & ppm & ppm \\
\hline 1 & 10.20 & $<1$ & $<5.5$ & 280.35 & $<1$ & $<10$ & $<0.5$ & 18.38 & 17.42 & 29.75 & 31.59 \\
\hline 2 & 4.62 & $<1$ & $<5.5$ & 244.99 & $<1$ & $<10$ & $<0.5$ & 11.54 & 18.14 & 25.82 & 20.43 \\
\hline 3 & 4.70 & $<1$ & $<5.5$ & 208.50 & $<1$ & $<10$ & $<0.5$ & 12.52 & 19.82 & 161.22 & 21.90 \\
\hline 4 & 5.67 & $<1$ & $<5.5$ & 223.99 & $<1$ & $<10$ & $<0.5$ & 11.14 & 16.89 & 25.62 & 28.61 \\
\hline 5 & 6.48 & $<1$ & $<5.5$ & 238.40 & $<1$ & $<10$ & $<0.5$ & 8.18 & 15.57 & 33.57 & 19.30 \\
\hline 6 & 7.40 & $<1$ & $<5.5$ & 246.88 & $<1$ & $<10$ & $<0.5$ & 11.39 & 8.03 & 45.24 & 19.69 \\
\hline 7 & 5.44 & $<1$ & $<5.5$ & 285.44 & $<1$ & $<10$ & $<0.5$ & 18.90 & 18.21 & 89.26 & 20.74 \\
\hline 8 & 13.11 & $<1$ & $<5.5$ & 229.27 & $<1$ & $<10$ & $<0.5$ & 34.19 & 20.78 & 80.14 & 46.32 \\
\hline 9 & 8.85 & $<1$ & $<5.5$ & 252.41 & $<1$ & $<10$ & $<0.5$ & 19.39 & 28.66 & 52.79 & 30.32 \\
\hline 10 & 13.85 & $<1$ & $<5.5$ & 196.47 & $<1$ & $<10$ & $<0.5$ & 9.8 & 11.73 & 43.28 & 12.18 \\
\hline 11 & 6.07 & $<1$ & $<5.5$ & 165.38 & $<1$ & $<10$ & $<0.5$ & 11.91 & 22.54 & 73.66 & 15.04 \\
\hline 12 & 4.30 & $<1$ & $<5.5$ & 223.59 & $<1$ & $<10$ & $<0.5$ & 17.61 & 14.58 & 132.86 & 18.77 \\
\hline 13 & 12.02 & $<1$ & $<5.5$ & 122.29 & $<1$ & $<10$ & $<0.5$ & 20.33 & 21.78 & 113.70 & 57.06 \\
\hline 14 & 14.78 & $<1$ & $<5.5$ & 155.832 & $<1$ & $<10$ & $<0.5$ & 20.19 & 16.39 & 59.30 & 20.90 \\
\hline 15 & 7.44 & $<1$ & $<5.5$ & 237.77 & $<1$ & $<10$ & $<0.5$ & 14.04 & 14.31 & 51.62 & 14.22 \\
\hline 16 & 5.32 & $<1$ & $<5.5$ & 393.83 & $<1$ & $<10$ & $<0.5$ & 15.32 & 13.07 & 39.40 & 13.63 \\
\hline 17 & 6.36 & $<1$ & $<5.5$ & $296 . .29$ & $<1$ & $<10$ & $<0.5$ & 14.38 & 16.71 & 39.20 & 15.6 \\
\hline \multirow[t]{3}{*}{ S. No. } & $\mathrm{Ga}$ & $\mathrm{Ge}$ & $\mathrm{Hf}$ & $\mathrm{La}$ & $\mathrm{Li}$ & Mo & $\mathrm{Nb}$ & $\mathrm{Ni}$ & $\mathrm{Pb}$ & $\mathrm{Rb}$ & $\mathrm{Sb}$ \\
\hline & 1.00 & 1.00 & 1.00 & 10.00 & 5.00 & 2.00 & 2.00 & 1.00 & 2.00 & 10.00 & 10.00 \\
\hline & $\mathrm{ppm}$ & ppm & ppm & $\mathrm{ppm}$ & Ppm & $\mathrm{ppm}$ & $\mathrm{ppm}$ & ppm & ppm & ppm & ppm \\
\hline 1 & 14.22 & $<1$ & 1.37 & 9.81 & 10.35 & $<2$ & 15.43 & 31.9 & 15.90 & $<10$ & $<10$ \\
\hline 2 & 10.39 & $<1$ & 1.23 & 5.96 & $<5$ & $<2$ & $<10$ & 14.81 & 26.07 & $<10$ & $<10$ \\
\hline 3 & 14.60 & $<1$ & 1.39 & 5.27 & $<5$ & $<2$ & 13.82 & 21.11 & 8.70 & $<10$ & $<10$ \\
\hline 4 & 10.27 & $<1$ & 1.27 & 5.86 & $<5$ & $<2$ & $<10$ & 10.91 & 33.79 & $<10$ & $<10$ \\
\hline 5 & 15.34 & $<1$ & 1.13 & 4.51 & 6.40 & $<2$ & 10.80 & 45.76 & 16.54 & $<10$ & $<10$ \\
\hline 6 & 10.13 & $<1$ & $<1$ & 5.11 & $<5$ & $<2$ & $<10$ & 16.65 & 31.25 & $<10$ & $<10$ \\
\hline 7 & 9.59 & $<1$ & 1.44 & 9.74 & 10.65 & $<2$ & $<10$ & 29.67 & 11.22 & $<10$ & $<10$ \\
\hline 8 & 18.90 & $<1$ & 2.29 & 16.68 & 14.71 & $<2$ & 25.66 & 50.19 & 16.90 & $<10$ & $<10$ \\
\hline 9 & 19.61 & $<1$ & 1.16 & 9.11 & 7.26 & $<2$ & 16.74 & 32.05 & 11.90 & $<10$ & $<10$ \\
\hline 10 & 17.80 & $<1$ & $<1$ & 5.55 & 5.67 & $<2$ & 17.43 & 22.15 & 8.40 & $<10$ & $<10$ \\
\hline 11 & 8.78 & $<1$ & $<1$ & 3.97 & $<5$ & $<2$ & 10.12 & 31.64 & 7.32 & $<10$ & $<10$ \\
\hline 12 & 12.26 & $<1$ & $<1$ & 7.90 & $<5$ & $<2$ & $<10$ & 16.00 & 9.49 & $<10$ & $<10$ \\
\hline 13 & 14.51 & $<1$ & 1.15 & 12.92 & 5.86 & $<2$ & 28.20 & 69.22 & 10.44 & $<10$ & $<10$ \\
\hline 14 & 19.41 & $<1$ & 1.17 & 8.46 & 11.81 & $<2$ & 23.15 & 26.95 & 11.31 & $<10$ & $<10$ \\
\hline 15 & 14.91 & $<1$ & $<1$ & 8.98 & 10.89 & $<2$ & 14.52 & 25.54 & 10.05 & $<10$ & $<10$ \\
\hline 16 & 10.45 & $<1$ & 1.10 & 7.31 & 7.65 & $<2$ & $<10$ & 22.21 & 10.38 & $<10$ & $<10$ \\
\hline 17 & 20.84 & $<1$ & $<1$ & 7.94 & 7.58 & $<2$ & 11.52 & 23.9 & 10.75 & $<10$ & $<10$ \\
\hline \multirow[t]{3}{*}{ S. No. } & $\mathrm{Sn}$ & $\mathrm{Sr}$ & $\mathrm{Ta}$ & $\mathrm{Th}$ & $\mathrm{U}$ & $\mathrm{V}$ & $\mathrm{W}$ & $\mathrm{Y}$ & $\mathrm{Zn}$ & $\mathrm{Zr}$ & \\
\hline & 10.00 & 1.00 & 1.00 & 1.00 & 5.00 & 1.00 & 5.00 & 1.00 & 1.00 & 1.00 & \\
\hline & ppm & ppm & ppm & ppm & ppm & ppm & ppm & ppm & ppm & ppm & \\
\hline 1 & $<10$ & 126.15 & $<1$ & 2.57 & $<0.5$ & 68.86 & 46.35 & 15.15 & 96.42 & 45.63 & \\
\hline 2 & $<10$ & 212.91 & $<1$ & $<1$ & $<0.5$ & 68.10 & 115.34 & 11.61 & 67.70 & 44.95 & \\
\hline 3 & $<10$ & 175.3 & $<1$ & 1.47 & $<0.5$ & 63.38 & 124.72 & 8.16 & 25.16 & 31.84 & \\
\hline 4 & $<10$ & 182.18 & $<1$ & $<1$ & $<0.5$ & 55.16 & 100.97 & 8.57 & 66.91 & 30.21 & \\
\hline 5 & $<10$ & 121.05 & $<1$ & 1.20 & $<0.5$ & 51.49 & 80.74 & 5.35 & 51.63 & 39.42 & \\
\hline 6 & $<10$ & 109.06 & $<1$ & $<1$ & $<0.5$ & 31.05 & $<5$ & 5.74 & 41.14 & 28.55 & \\
\hline 7 & $<10$ & 194.65 & $<1$ & 1.86 & $<0.5$ & 90.95 & 45.16 & 12.54 & 37.11 & 53.06 & \\
\hline 8 & $<10$ & 168.44 & 2.99 & 3.51 & $<0.5$ & 124.44 & 9.58 & 24.50 & 92.95 & 91.96 & \\
\hline 9 & $<10$ & 183.81 & 1.24 & 2.12 & $<0.5$ & 91.73 & 65.24 & 13.42 & 65.28 & 60.12 & \\
\hline 10 & $<10$ & 120.92 & $<1$ & $<1$ & $<0.5$ & 42.19 & 58.19 & 9.68 & 102.59 & 30.85 & \\
\hline 11 & $<10$ & 90.09 & 3.31 & 2.68 & $<0.5$ & 30.80 & 132.47 & 5.74 & 26.56 & 30.59 & \\
\hline 12 & $<10$ & 210.37 & $<1$ & 1.34 & $<0.5$ & 63.93 & 19.48 & 9.78 & 24.91 & 36.14 & \\
\hline 13 & $<10$ & 247.13 & 7.57 & $<1$ & $<0.5$ & 120.71 & $<5$ & 15.27 & 39.52 & 67.40 & \\
\hline 14 & $<10$ & 133 & $<1$ & 1.45 & $<0.5$ & 103.41 & 28.15 & 12.73 & 51.34 & 52.69 & \\
\hline 15 & $<10$ & 143.91 & $<1$ & 1.69 & $<0.5$ & 79.16 & 72.56 & 11.49 & 42.19 & 59.39 & \\
\hline 16 & $<10$ & 176.64 & 2.14 & 1.74 & $<0.5$ & 68.74 & 57.13 & 8.97 & 31.88 & 45.31 & \\
\hline 17 & $<10$ & 169.07 & 4.36 & 2.95 & $<0.5$ & 78.76 & 69.60 & 9.78 & 28.51 & 39.15 & \\
\hline
\end{tabular}

$\mathrm{Ag}$ silver, $\mathrm{As}$ arsenic, $\mathrm{Ba}$ barium, $\mathrm{Be}$ beryllium, $\mathrm{Bi}$ bismuth, $\mathrm{Cd}$ cadmium, $\mathrm{Ce}$ cerium, $\mathrm{Co}$ cobalt, $\mathrm{Cr}$ chromium, $\mathrm{Cu}$ copper

$\mathrm{Ga}$ gallium, $\mathrm{Ge}$ germanium, $H f$ hafnium, $L a$ lanthanum, $L i$ lithium, $M o$ molybdenum, $N b$ niobium, $N i$ nickel, $P b$ lead, $R b$ rubidium, $S b$ antimony $\mathrm{Sn}$ tin, $\mathrm{Sr}$ strontium, $\mathrm{Ta}$ tantalum, $\mathrm{Th}$ thorium, $U$ uranium, $V$ vanadium, $W$ tungsten, $Y$ yttrium, $Z n$ zinc, $Z r$ zirconium

et al. (2016) has been used to identify the different types of sandstone. This binary diagram illustrates that the examined samples are litharenite in general and only 3 samples are greywacke, arkoses sub-litharenite (Fig. 5b).
Using the ternary plot of $\mathrm{Fe}_{2} \mathrm{O}_{3}+\mathrm{MgO}-\mathrm{Na}_{2} \mathrm{O}-\mathrm{K}_{2} \mathrm{O}$, which was established and modified by different authors such as Blatt et al. (1972) and Madukwe et al. (2016), has been used to differentiate the silicate types. This ternary plot 

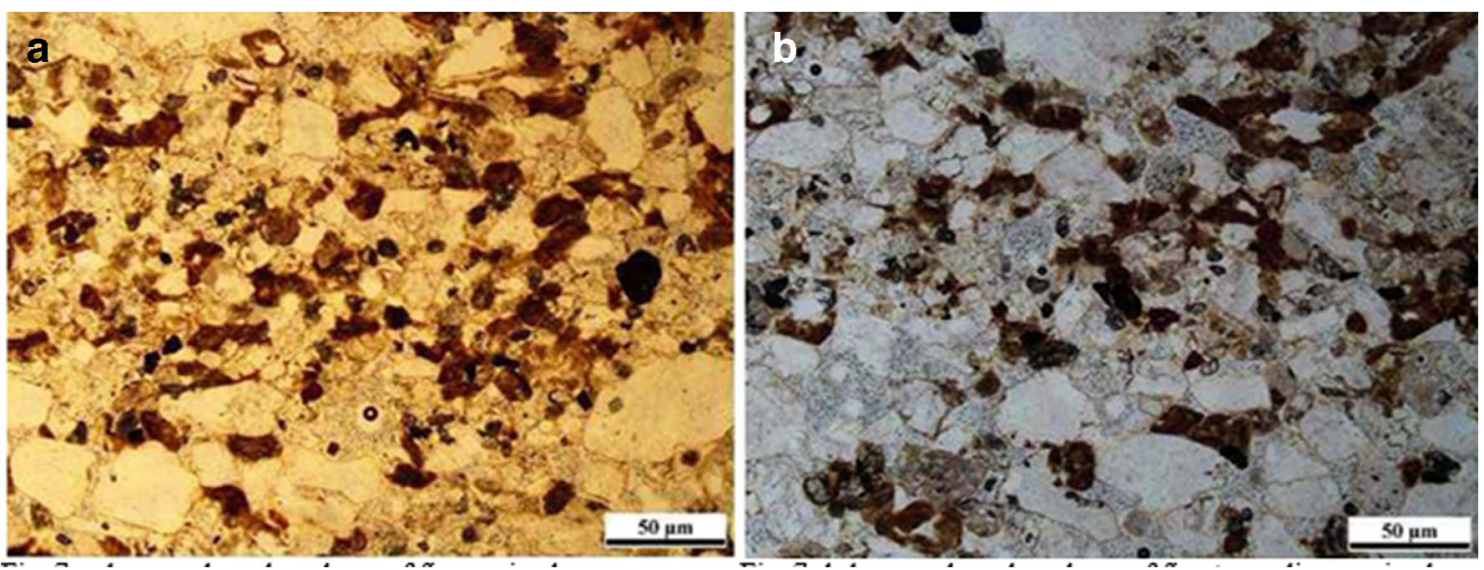

Fig. 4 Paleosol made up of fine-grained sandstone and siltstone facies. Quartz grains are ill-sorted, sub-angular to sub-rounded

illustrates that the vast majority of the examined sandstones fall in the field of sodic sandstone and few samples fall in the field of ferromagnesian potassic sandstones (Fig. 5c). In addition, plotting the ternary diagram of $\mathrm{SiO} 2-\mathrm{Al} 2 \mathrm{O} 3-\mathrm{Fe} 2 \mathrm{O} 3$ which was developed and modified by Dury (1951), Jing et al. (2013), and El-Desoky et al. (2015) has been used in this study to illustrate that the examined sandstone falls mostly in the ferruginous silicates field, except one sample falls in the silica (quartz) field (Fig. 5d).

\section{Source area weathering and mineral composition}

Shao et al. (2012) developed a ternary diagram of $\mathrm{Al}_{2} \mathrm{O}_{3}$ $\mathrm{CaO}-\mathrm{K}_{2} \mathrm{O}$ to deduce degree of weathering. Using this plot, the degree of weathering of the examined sandstones ranges from weak to intermediate chemical weathering (Fig. 6a). Furthermore, $\mathrm{K}_{2} \mathrm{O}$ against $\mathrm{Al}_{2} \mathrm{O}_{3}$ binary plot developed and modified by Kohonen (1995) and Obasi and Madukwe (2016) was used to determine the mineral contents. This binary plot shows clearly that the examined sandstones fall close to the feldspar field rather than the muscovite field, which reflects weak to moderate weathering (Fig. 6b). Nesbitt and Young (1982, 1984, 1989) used the ternary plot of $\mathrm{Al}_{2} \mathrm{O}_{3}-\left(\mathrm{CaO}+\mathrm{Na}_{2} \mathrm{O}\right)-\mathrm{K}_{2} \mathrm{O}$ to deduce weathering trends to determine the relation between mineral composition, source rocks, and weathering paths. Plotting the examined samples on this ternary diagram displays an intermediate weathering history with gabbros, tonalite, and granodiorite trends (Fig. 6c). In addition, $\mathrm{Fe}_{2} \mathrm{O}_{3} / \mathrm{SiO}_{2}$ versus $\mathrm{Al}_{2} \mathrm{O}_{3} / \mathrm{SiO}_{2}$ binary plot can be used to distinguish source mineralogy (Herron 1988). Using this plot, the vast majority of the sandstone samples were consisted of quartz (Fig. 6d).

\section{Climate and effects of diagenesis}

The applicability of the ratios of $\mathrm{SiO}_{2} /\left(\mathrm{Al}_{2} \mathrm{O}_{3}+\mathrm{K}_{2} \mathrm{O}+\right.$ $\mathrm{Na}_{2} \mathrm{O}$ ) for paleo-climatic condition during deposition of the sediments is well recognized by many authors
(Wronkiewicz and Condie 1987; Madukwe et al. 2016). Plotting the examined samples on binary diagram of $\mathrm{SiO}_{2} /$ $\left(\mathrm{Al}_{2} \mathrm{O}_{3}+\mathrm{K}_{2} \mathrm{O}+\mathrm{Na}_{2} \mathrm{O}\right)$ displays reasonable semi-arid to semi-humid climatic circumstances in the study area during the Miocene-Pliocene times (Fig. 7a). Postdepositional variation can significantly alter geochemistry of sedimentary rocks. Among the most important diagenetic processes are silicification and K-metasomatism which might result from hydrothermal metasomatism or syn-depositional interaction with water at low temperatures (Jacobson et al. 2003). The binary discernment plot of $\log \left(\mathrm{SiO}_{2} / \mathrm{Al}_{2} \mathrm{O}_{3}\right)$ versus $\log \left(\mathrm{K}_{2} \mathrm{O} / \mathrm{Na}_{2} \mathrm{O}\right)$ refers to postdepositional processes affected the examined sandstones throughout syn-depositional interaction with water at low temperatures (Fig. 7b).

\section{Environments of deposition}

The binary diagram of $\mathrm{Fe}_{2} \mathrm{O}_{3}$ versus $\mathrm{MgO}$ which was developed and modified by Ratcliffe et al. (2007) and Madukwe et al. (2015) characterizes and differentiates marine from non-marine and deltaic sandstones. Plotting the examined samples on this diagram, it shows clearly that all examined samples are non-marine and deltaic sandstone except two samples which fall in the field of marine origin (Fig. 8a). The relation between $\log \mathrm{K}_{2} \mathrm{O} / \mathrm{Al}_{2} \mathrm{O}_{3}$ versus $\log \mathrm{MgO} / \mathrm{Al}_{2} \mathrm{O}_{3}$ was used to discriminate marine from non-marine sandstones (Roaldest 1978; El-Desoky et al. 2015). Applying this relation in the present study shows that most of the examined samples fall in non- marine field, while a few of them (3 samples) fall within the marine field (Fig. 8b).

Furthermore, the ternary diagram of $\mathrm{MgO}-\mathrm{Fe}_{2} \mathrm{O}_{3}-$ $\left(\mathrm{SiO}_{2} / \mathrm{Al}_{2} \mathrm{O}_{3}\right)$ developed and modified by Ratcliffe et al. (2007) and Madukwe and Bassey (2015) categorizes and discriminates the marine from non-marine and deltaic sandstones. This plot confirms that all the examined 
a

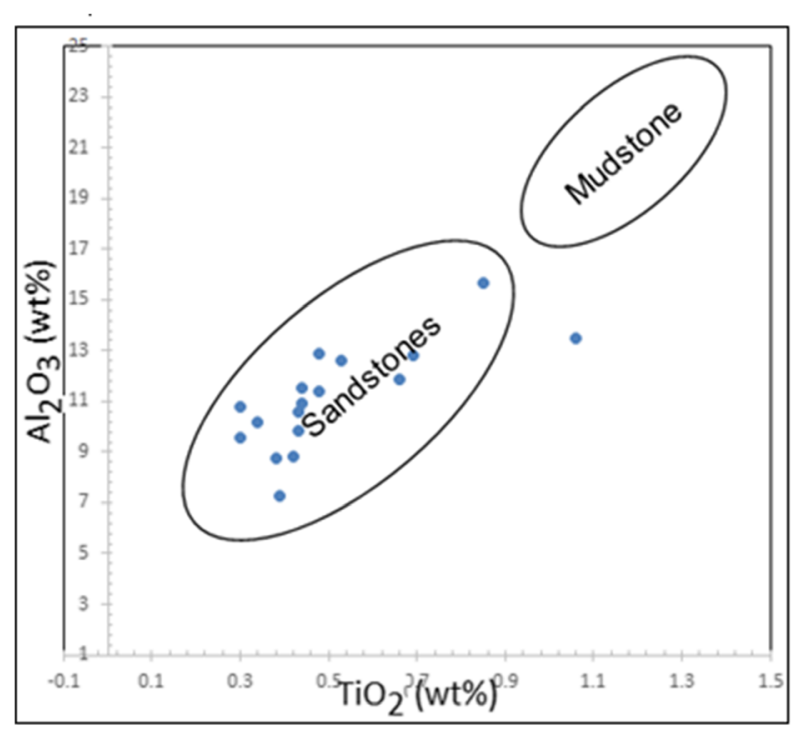

C

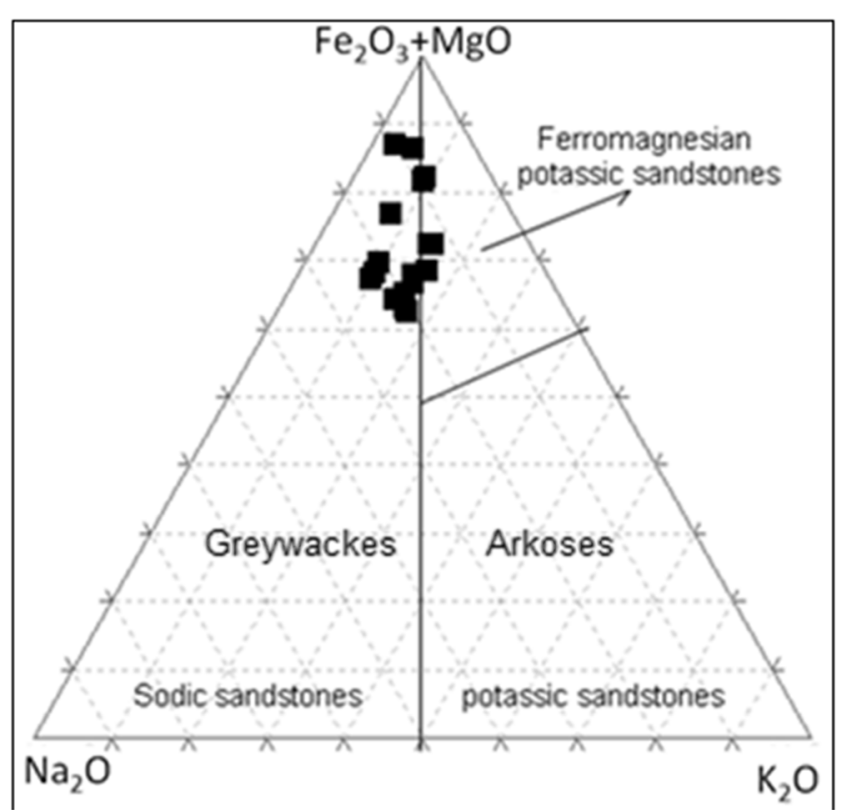

b

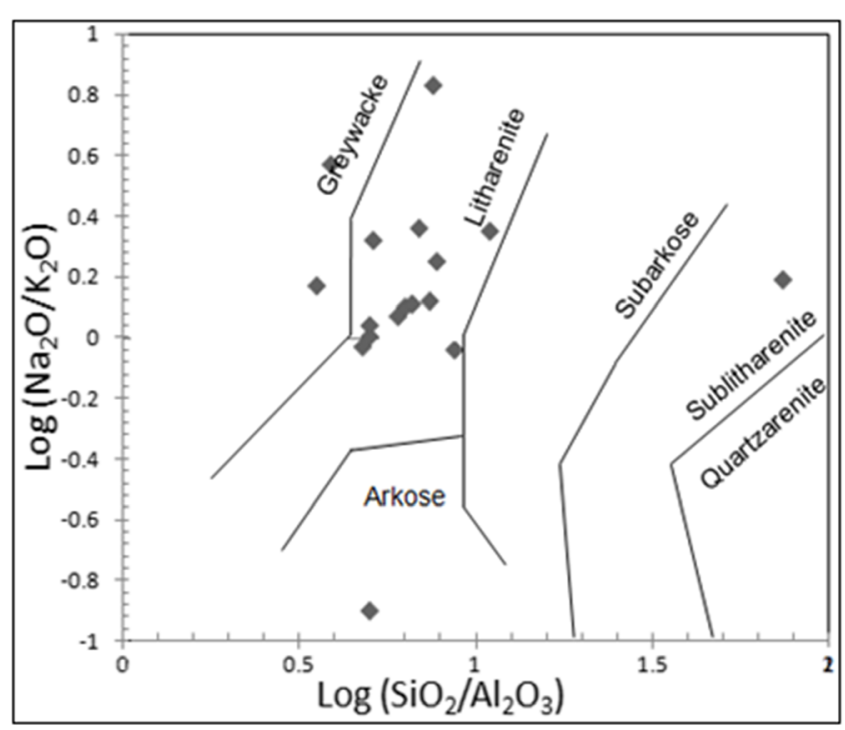

d

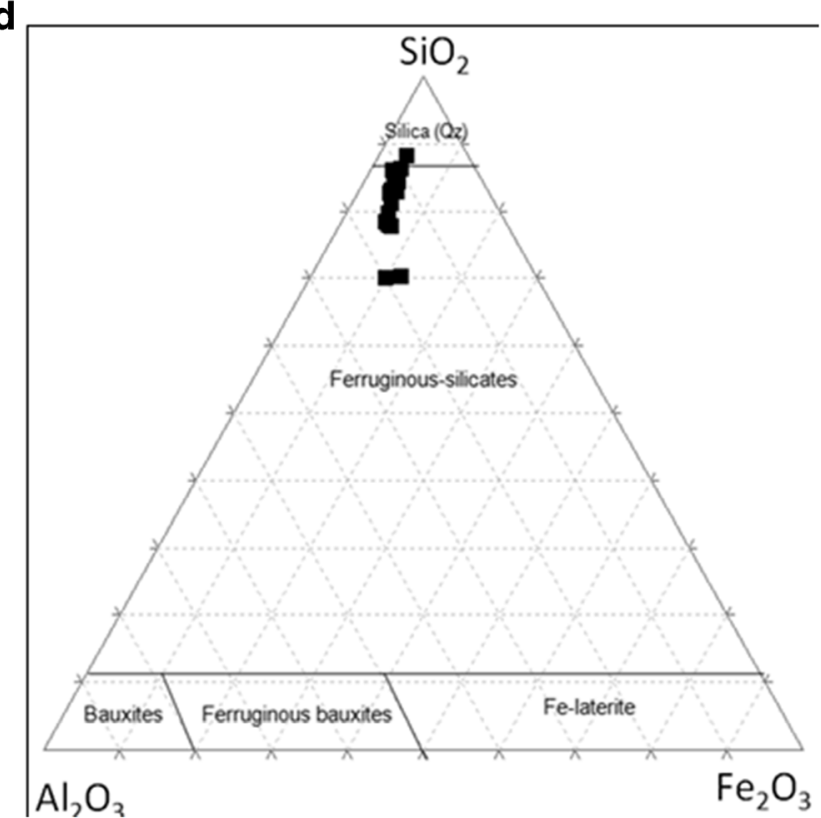

Fig. 5 a-d Binary and ternary chemical composition discrimination plots of the studied sandstones

samples fall in the field of non-marine and deltaic sandstones (Fig. 8c). Ni/Co versus $\mathrm{V} / \mathrm{Cr}$ binary plot was also used to evaluate the paleoredox conditions (Roaldest 1978; Noori and Rais 2014). This binary plot shows that the examined sandstones were deposited in an environment that has oxic conditions (Fig. 8d).

\section{Paleosols and climate}

Paleosols have several geologic applications ranging from landscape reconstruction to paleo-climatic studies (Kraus 1999). The paleo-climatic importance of paleosols stems from studies of quaternary soil development, which have shown that some pedogenic features can be quantitatively related to soil-forming factors such as climate. Continental successions with multistory paleosols can provide a continuous record of ancient climatic conditions and climatic changes through time (Kraus 1999). In addition, paleosol-landscape analysis can produce a clearer, more complete picture of the environmental conditions and processes operating in ancient continental basins (Purser and Bosence 1998). Paleosols are not only used to interpret ancient climatic but can also be used to estimate paleo-precipitation and paleo-temperature (Kraus 1999).

Detrital clays are common in immature paleosols developed in climates that are unfavorable for pedogenesis and typically include minerals resistant to chemical weathering (Singh et al. 2016). For example, igneous quartz, muscovite, secondary microcrystalline quartz, smectite, vermiculite, illite, 
a

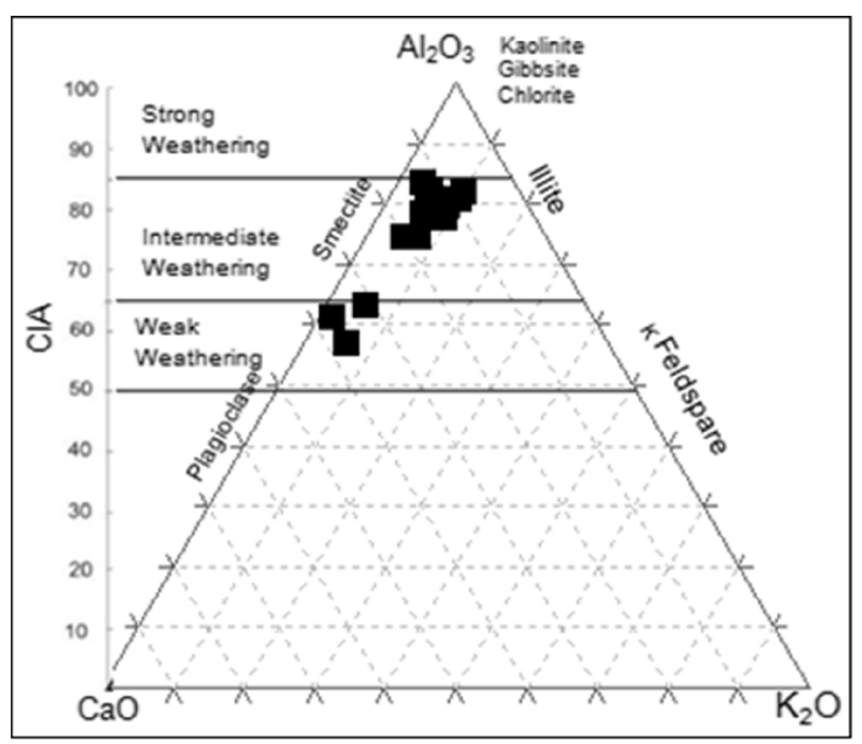

b

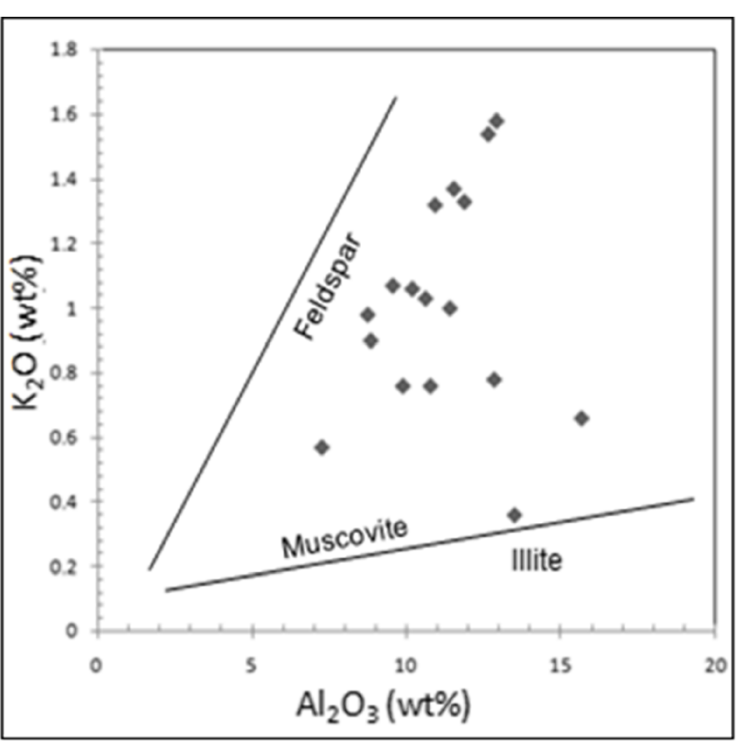

C

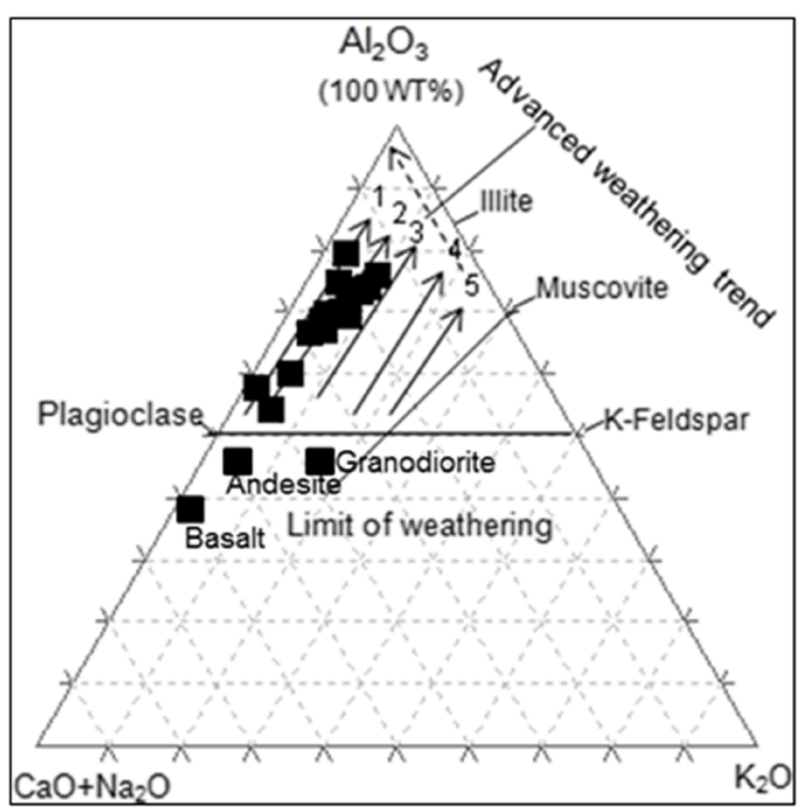

d

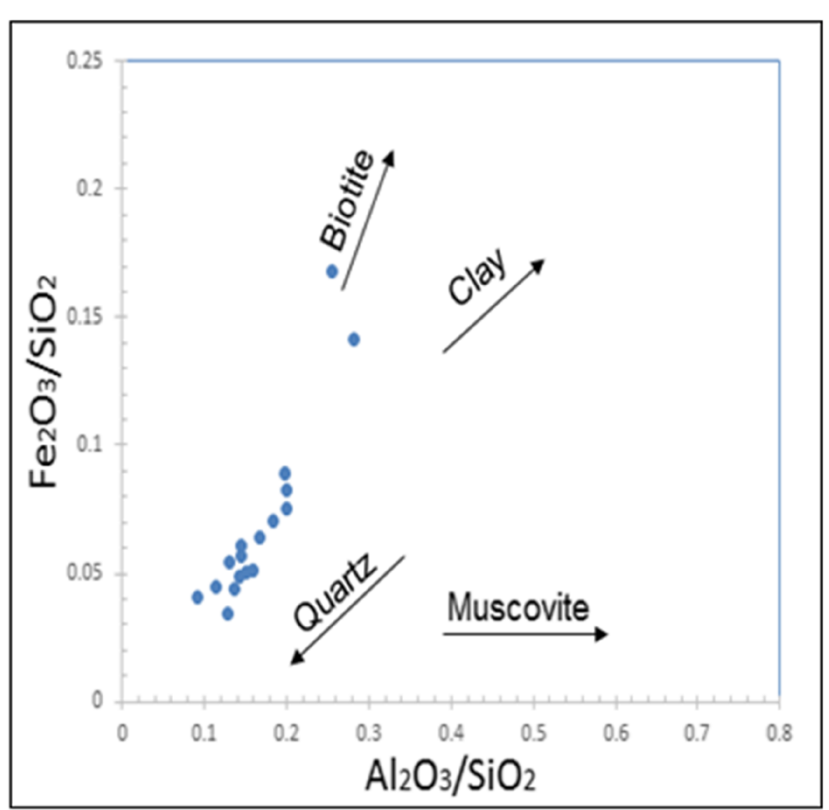

Fig. 6 a-d Binary and ternary plots of source area weathering and mineral composition of the tested sandstones

and kaolinite are ubiquitous in the clay fractions of paleosols developed in sedimentary strata (Tabor and Myers 2015). In the study area, some paleosol horizons were developed (Figs. 3 and 4). Figure 3 shows medium- to coarse-grained pebbly sandstone facies. It is made up of quartz, rock fragments, feldspars within detrital clay, and iron oxide matrix. These detrital clays refer to weak to moderate chemical weathering in semi-arid to semi-humid climatic conditions with strong and sporadic rainfall (Tabor and Myers 2015). Figure 4 shows paleosol made up of fine-grained sandstone/ siltstone facies. Quartz grains are ill sorted, sub-angular to sub-rounded.

\section{Discussion}

Sedimentary rocks formed under different climatic conditions have variable geochemical characteristics (Ratcliffe et al. 2007; Obasi and Madukwe 2016; Madukwe et al. 2016). Geochemical data and approaches are very useful to constrain and evaluate depositional environments of sedimentary rocks, weathering, and climate (Madukwe et al. 2015; Madukwe and Bassey 2015 and Roaldest 1978). Major elements provide valuable information on both the rock compositions and weathering of the sedimentary rocks (El-Desoky et al. 2015; Ratcliffe et al. 2007; Smaill 2015). In addition, these major 

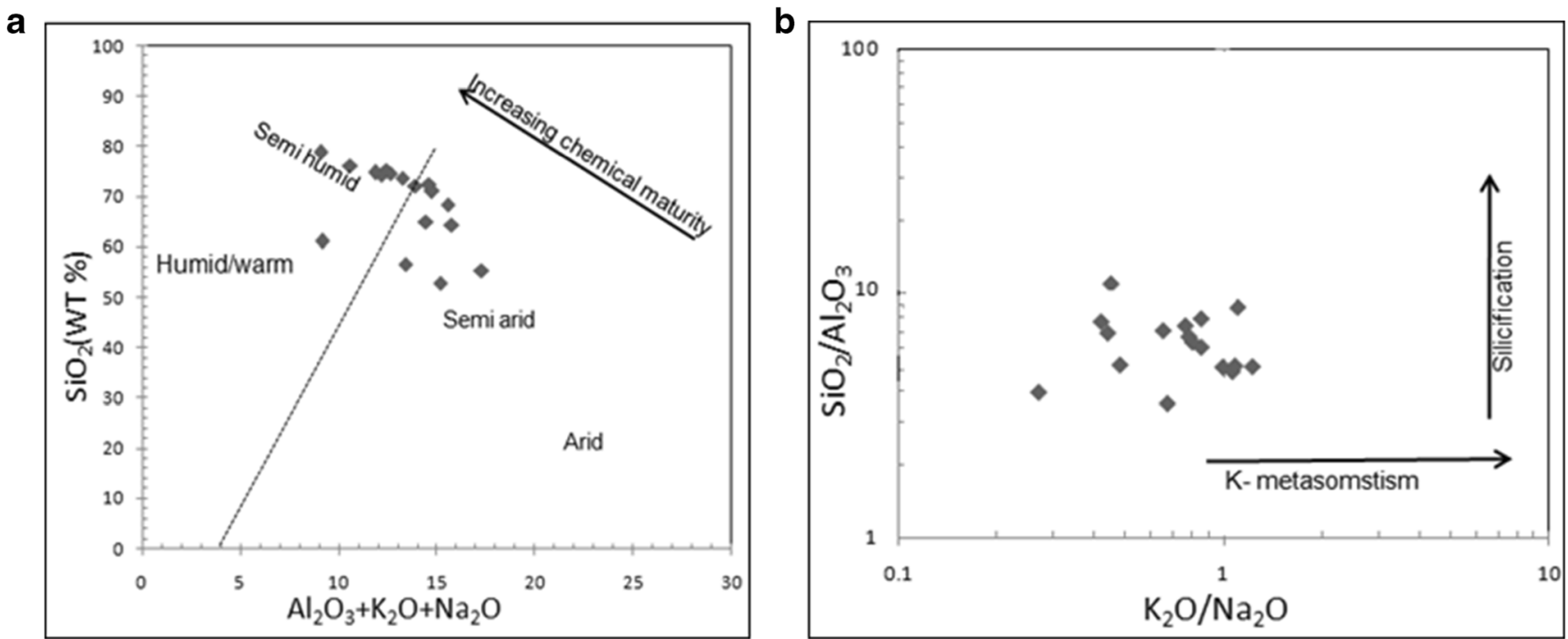

Fig. 7 a, b Binary diagrams of climatic variations and post-depositional variation of the studied sandstones

elements also describe the characteristics and composition of the source rocks (Tabor and Myers 2015). Furthermore, major and trace elements and their various binary and ternary plots with discrimination functions are often applicable for climate and depositional environments of the sedimentary basins. However, these applications are not always usable for certain local settings, although some relationships between climatic conditions and geochemical composition of sediments could be documented.

The source of siliciclastic sedimentary rocks is partially or totally of igneous rocks. Crystalline rocks release their component minerals due to chemical, physical, and biological weathering as occurred in the study area. Chemical weathering is the main process accountable for obliteration of feldspars and construction of secondary clay minerals. During transportation, erosion and sorting of materials formed in weathering profiles yield sands and muds where the coarser portion is combined into sands and the secondary clay minerals are incorporated into muds. Textural, mineralogical, and bulk chemical analyses of these siliciclastic sediments offer vision into weathering circumstances affecting the source rocks. It also provides insight into the types of source rocks providing weathering materials for the deposited sediments. Weathering products form the source materials of soils and sedimentary rocks. The final composition of soil and terrigeneous sedimentary rock reflects the composition of the source rock. Many minerals of source rock are destroyed totally during weathering, while chemically resistant minerals are released from the decaying and disintegrating rock and accumulate as residues. Throughout this process, new minerals such as ferric oxides and clay minerals may form in situ in the soils. Therefore, soils are made up of persistence accumulations of minerals and rock fragments resulted from the parent rocks plus new minerals formed at the weathering position. Accordingly, soil composition is controlled not only by the parent-rock composition but also by the nature, strength, and duration of weathering and soil-forming processes. $\mathrm{Al}_{2} \mathrm{O}_{3}-\left(\mathrm{CaO}+\mathrm{Na}_{2} \mathrm{O}+\right.$ $\left.\mathrm{K}_{2} \mathrm{O}\right)-\left(\mathrm{Fe}_{2} \mathrm{O}_{3}+\mathrm{MgO}\right)$ plot designates a non-homogenous source between the weathering trends of basaltic and granitic rocks and moderately affected by the chemical weathering. $\mathrm{Al}_{2} \mathrm{O}_{3}$ versus $\mathrm{SiO}_{2}$ plot refers to the absence of the biogenic contribution to the examined sandstone samples. $\mathrm{Al}_{2} \mathrm{O}_{3}-(\mathrm{CaO})-\mathrm{K}_{2} \mathrm{O}$ plot shows that the degree of weathering ranges from an intermediate to weak. $\left(\mathrm{Na}_{2} \mathrm{O}+\mathrm{K}_{2} \mathrm{O}\right) /\left(\mathrm{Al}_{2} \mathrm{O}_{3}+\mathrm{Na}_{2} \mathrm{O}+\mathrm{K}_{2} \mathrm{O}\right)$ versus $\left(\mathrm{SiO}_{2}+\mathrm{Na}_{2} \mathrm{O}\right.$ $\left.+\mathrm{K}_{2} \mathrm{O}\right) /\left(\mathrm{SiO}_{2}+\mathrm{Al}_{2} \mathrm{O}_{3}+\mathrm{Na}_{2} \mathrm{O}+\mathrm{K}_{2} \mathrm{O}\right)$ plot indicates that feldspars are altered to clay minerals and $\mathrm{K}_{2} \mathrm{O}$ deriving from altered feldspars is captured by $\mathrm{Na}_{2} \mathrm{O}$ in illite and montmorillonite. $\mathrm{K}_{2} \mathrm{Ox} 10$ - $\mathrm{Al}_{2} \mathrm{O}_{3} / 2-\mathrm{MgO}$ plot shows an intermediate composition between illite and chlorite. $\mathrm{K}_{2} \mathrm{O}$ versus $\mathrm{Al}_{2} \mathrm{O}_{3}$ plot shows that these sandstones have more feldspar than muscovite and illite, which reflects weak to moderate weathering. $\mathrm{Al}_{2} \mathrm{O}_{3}-\left(\mathrm{CaO}+\mathrm{Na}_{2} \mathrm{O}\right)$ $\mathrm{K}_{2} \mathrm{O}$ plot indicates an intermediate weathering history with gabbros, tonalite, and granodiorite trends.

Climate controls both the degree of chemical weathering profiting and the rate of weathering profiles formation on the crystalline rocks. The strength of tectonism controls the rate of material denudation from source areas (Alqahtani and Khalil 2019). The mineralogical and bulk chemical compositions of sands and muds derived from these weathering profiles thus are controlled by, and reflect, relative rates of chemical weathering and denudation.

Evidences that the Arabian Peninsula was significantly less arid in the Pliocene-Early Pleistocene and probably back to Middle Miocene come from the Wadi Birk (Robin 2004; Bailey et al. 2015). It was part of a river system that formerly 
a

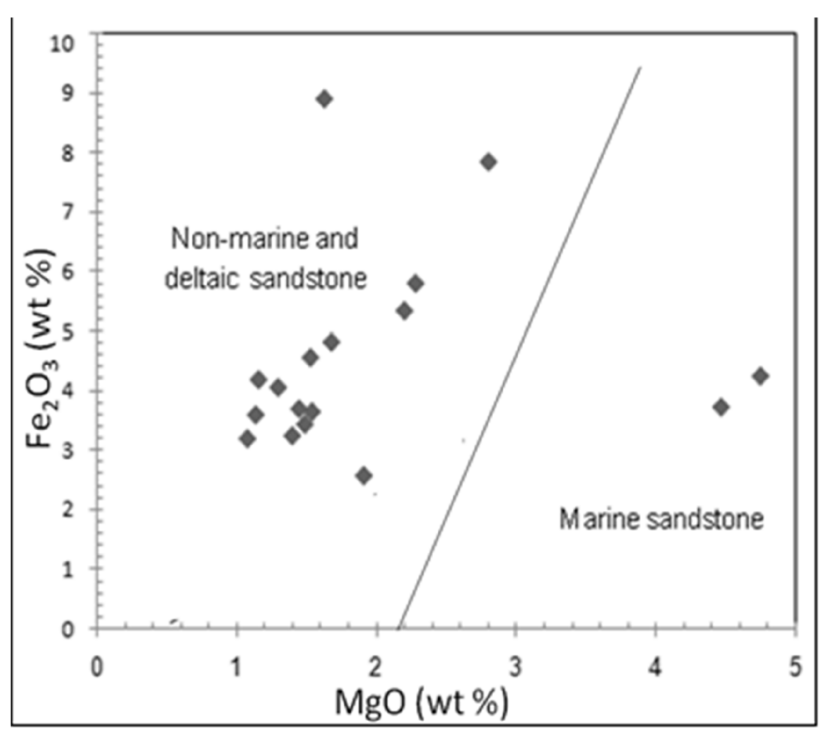

C

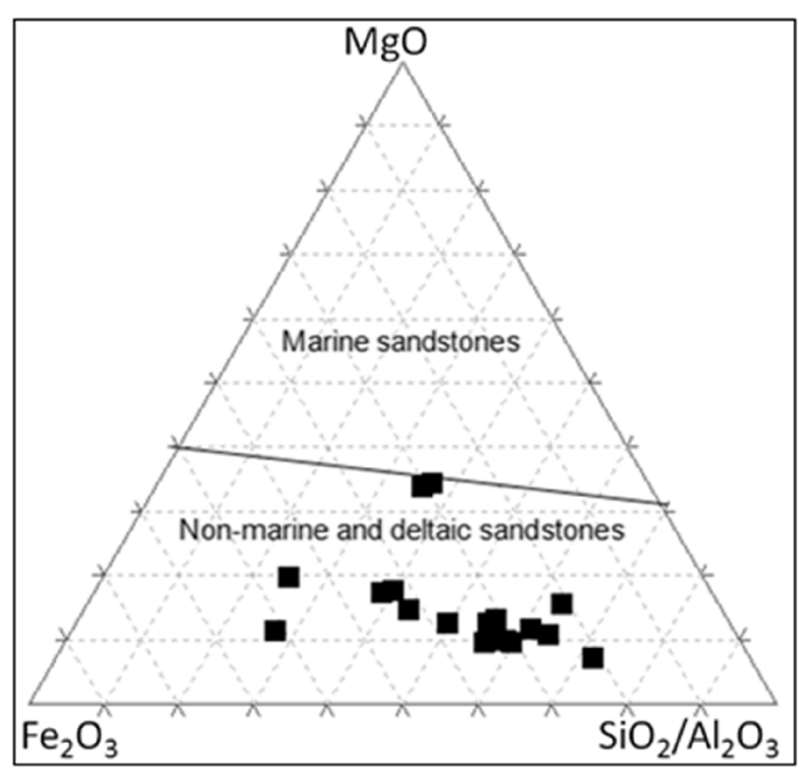

b

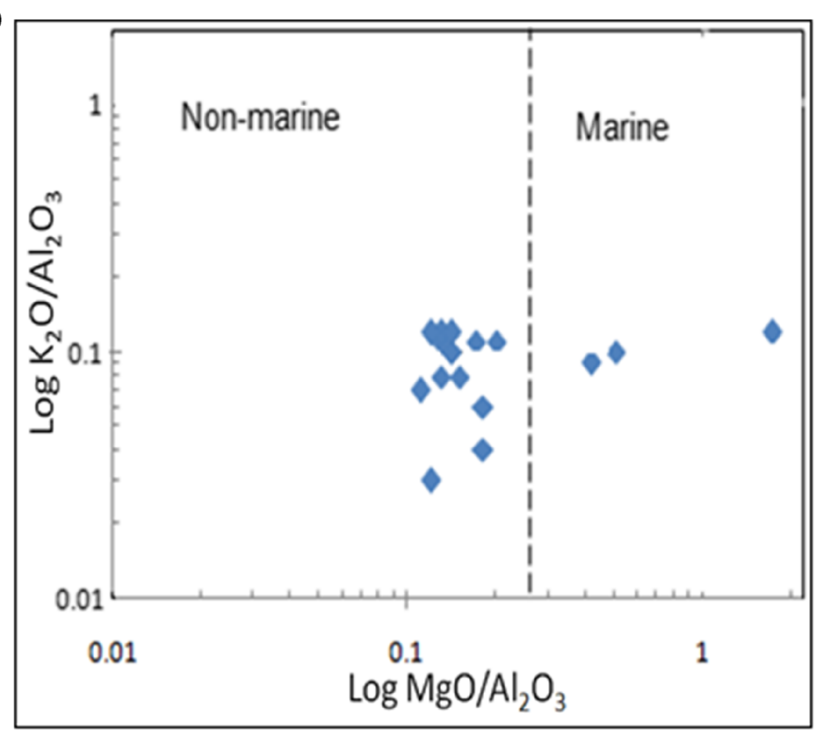

d

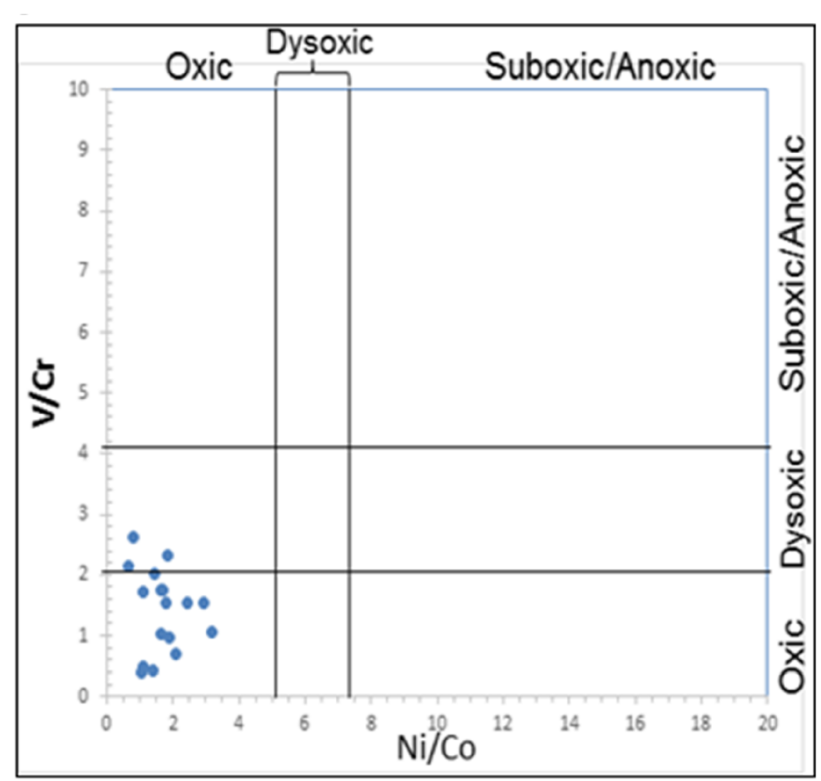

Fig. 8 a-d Binary and ternary discrimination plots of depositional environments of the examined sandstones

covered the entire Arabian Shelf and terminated in a delta fan with a radius of about $150 \mathrm{~km}$ (Purser and Bosence 1998). Additional evidences for moister conditions come from fossil localities in the An Nafud Desert in northwestern Saudi Arabia (Malaren et al. 2009). Their remains were found in lacustrine deposits. $\mathrm{SiO}_{2} / \mathrm{Al}_{2} \mathrm{O}_{3}$ versus $\mathrm{Fe}_{2} \mathrm{O} 3 / \mathrm{K}_{2} \mathrm{O}$ plot indicates Fe-sand. Both $\mathrm{SiO}_{2} / \mathrm{Al}_{2} \mathrm{O}_{3}$ versus $\mathrm{K}_{2} \mathrm{O} / \mathrm{Na}_{2} \mathrm{O}$ and $\log$ $\left(\mathrm{Na}_{2} \mathrm{O} / \mathrm{K}_{2} \mathrm{O}\right)$ versus $\log \left(\mathrm{SiO}_{2} / \mathrm{Al}_{2} \mathrm{O}_{3}\right)$ plots denote mostly to litharenitic sandstones. $\log \left(\mathrm{SiO}_{2} / \mathrm{Al}_{2} \mathrm{O}_{3}\right)$ versus $\log \left(\mathrm{K}_{2} \mathrm{O} /\right.$ $\mathrm{Na}_{2} \mathrm{O}$ ) plot designates arkoses sandstones, while log $\left(\left(\mathrm{Fe}_{2} \mathrm{O}_{3}+\mathrm{MgO}\right) /\left(\mathrm{K}_{2} \mathrm{O}+\mathrm{Na}_{2} \mathrm{O}\right)\right)$ versus $\log \left(\mathrm{K}_{2} \mathrm{O} / \mathrm{Na}_{2} \mathrm{O}\right)$ plot refers arkoses and litharenitic composition. $\left(\mathrm{Fe}_{2} \mathrm{O}_{3}+\mathrm{MgO}\right)-$ $\mathrm{Na}_{2} \mathrm{O}-\mathrm{K}_{2} \mathrm{O}$ plot refers mostly to sodic and rarely to ferromagnesian potassic sandstones, while $\mathrm{SiO}_{2}-\mathrm{Al}_{2} \mathrm{O}_{3}-\mathrm{Fe}_{2} \mathrm{O}_{3}$ plot indicates ferruginous silicates. $\mathrm{SiO}_{2}$ versus $\left(\mathrm{Al}_{2} \mathrm{O}_{3}+\mathrm{K}_{2} \mathrm{O}+\right.$ $\mathrm{Na}_{2} \mathrm{O}$ ) plot demonstrates reasonable semi-arid to semi-humid climatic circumstances in the study area during the Miocene Pliocene times. $\log \mathrm{K}_{2} \mathrm{O} / \mathrm{Al}_{2} \mathrm{O}_{3}$ versus $\log \mathrm{MgO} / \mathrm{Al}_{2} \mathrm{O}_{3}$ plot indicates mostly to non-marine depositional environment, while both $\mathrm{Fe}_{2} \mathrm{O}_{3}$ versus $\mathrm{MgO}$ binary and $\mathrm{MgO}-\mathrm{Fe}_{2} \mathrm{O}_{3^{-}}$ $\mathrm{SiO}_{2} / \mathrm{Al}_{2} \mathrm{O}_{3}$ ternary plots demonstrate the non-marine and deltaic sandstones. $\mathrm{Ni} / \mathrm{Co}$ versus $\mathrm{V} / \mathrm{Cr}$ plot demonstrates oxic depositional conditions and $\mathrm{Ni} / \mathrm{Co}$ versus (Fig. 8d). $\mathrm{Al}_{2} \mathrm{O}_{3} \times 5$ $-\mathrm{SiO}_{2}-\mathrm{CaOx} 2$ ternary plot shows the examined sandstones fall in the quartz field (sandstones) and deposited on mud flats (Fig. 8c). V versus Ni plot indicates the vast majority of the examined samples deposited in terrestrial to marine-terrestrial depositional environments. 


\section{Conclusions}

Geochemical data analysis and approaches including major and trace elements are very useful for constraining and evaluating the climatic control on the depositional environments of Bathan Formation. The analysis carried out in this study displays reasonable semi-arid to semi-humid climatic circumstances in the study area during the Miocene-Pliocene times. The analysis refers to post-depositional silicification processes affected the examined sandstones throughout syndepositional interaction with water at low temperatures. In addition, the depositional environments for these sandstones are interpreted to be terrestrial (non-marine, mainly fluvial) to marine-terrestrial (mainly deltaic) depositional environments. It reveals that the sandstones of these siliciclastic sequences were deposited close to coastal plain of the Red Sea and suffered from weak to intermediate chemical weathering and intense physical induration under semi-arid to semi-humid climatic conditions mostly in a non-marine (fluvial/alluvial-lacustrine) environment. Furthermore, the multistory paleosols described herein provide a continuous record of climatic fluctuations from semi-arid to semi-humid.

Acknowledgments This research was completed at the Department of Petroleum Geology and Sedimentology at King Abdulaziz University. The authors wish to thank all faculty members of the department for their support during this study. Saudi Geological Survey (SGS) is gratefully acknowledged for their help in providing major oxide analysis used in this study. Special thanks go to the anonymous reviewers for their critical and constructive comments. Furthermore, we thank Chief Editor Prof. Abdullah Al-Amri and Associate Editor for handling the manuscript inquiries.

Open Access This article is licensed under a Creative Commons Attribution 4.0 International License, which permits use, sharing, adaptation, distribution and reproduction in any medium or format, as long as you give appropriate credit to the original author(s) and the source, provide a link to the Creative Commons licence, and indicate if changes were made. The images or other third party material in this article are included in the article's Creative Commons licence, unless indicated otherwise in a credit line to the material. If material is not included in the article's Creative Commons licence and your intended use is not permitted by statutory regulation or exceeds the permitted use, you will need to obtain permission directly from the copyright holder. To view a copy of this licence, visit http://creativecommons.org/licenses/by/4.0/.

\section{References}

Alqahtani FA, Khalil MK (2015) Depositional environments of the Miocene-Pliocene siliciclastic succession, Al Rehaili area, north of Jeddah, Saudi Arabia. J Geol Soc India 86:706-716

Alqahtani FA, Khalil MK (2019) Geochemical analysis and tectonic evaluation of the Miocene-Pliocene sequence at Al Rehaili area, Northern Jeddah, Saudi Arabia. Arab J Geosci 12:323

Álvarez JOI (2005) Geochemical study of the mesoproterozoic BeltPurcell super-group, Western North America: Implications for provenance, weathering and diagenesis. A Thesis Submitted to the
College of Graduate Studies and Research in Partial Fulfillment of the Requirements for the Degree of Doctor of Philosophy in the Department of Earth Sciences University of Saskatchewan Saskatoon, $243 \mathrm{p}$

Armient P, Messiga B, Vannucci R (1998) Sand provenance from major and trace element analyses of bulk rock and sand grains. Terra Antartica 5(3):589-599

Bailey G, Deves M, Inglis R, Williams M, Momber G, Sakellariou D, Sinclair M, Rousakis G, Al Ghamdi S, Alsharekh A (2015) Blue Arabia: palaeolithic and underwater survey in SW Saudi Arabia and the role of coasts in Pleistocene dispersals. Quaternary International 382:42-57

Barbera G, Mazzoleni P, Critelli S, Pappalardo A, Lo-Giudice A, Cirrincione R (2006) Provenance of shales and sedimentary history of the Monte Soro Unit. Sicily Per Mineral 75(2-3):313-330

Blatt H, Middleton GV, Murray RC (1972) Origin of sedimentary rocks. Printice Hall, New Jersey, p 634

Chen B, Liu G, WuD SR (2016) Comparative study on geochemical characterization of the Carboniferous aluminous argillites from the Huainan Coal Basin, China. Turkish J Earth Sci 25:274-287

Dury GH (1951) Quantitative measurement of available relief and of depth of dissection. Geol Mag 88:339-343

El-Desoky H, El-Rahmany M, Farouk S, Ahmed Khalil A, Fahmy W (2015) Geochemical characteristics of goethite-bearing deposits in the Dakhla - Kharga Oases, Western Desert, Egypt. International Journal of Scientific Engineering and Applied Science (IJSEAS) 1(8):72-85

Ghandour M, AL-Washmi A (2013) Stratigraphic architecture of the fluvio-lacustrine deposits Bathan Formation, Al-Rehaili area, North Jeddah, Saudi Arabia. Arab Jour Geosci 6:995-1010

Herron MM (1988) Geochemical classification of terrigeneous sands and shales from core or log data. Journal of Sedimentary Petrology 58: 820-829

Jacobson AD, Blum JD, Chamberlian CP, Craw D, Koons PO (2003) Climate and tectonic controls on chemical weathering in the New Zealand Southern Alps. Geochim Cosmochim Acta 37:29-46

Jing G, Huang Z, Fan H, Zhongguo Jin C, Yan Z, Zhang J (2013) Mineralogy, geochemistry, and genesis of lateritic bauxite deposits in the Wuchuan-Zheng'an-Daozhen area, Northern Guizhou Province, China. J Geochem Explor 130:44-59

Johnsson MJ (1993) The system controlling the composition of clastic sediments: in Johnsson. In: Johnsson MJ, Basu A (eds) Processes controlling the composition of clastic sediments. Geological Society of America Special Paper, Boulder, pp 1-19

Kohonen J (1995) From continental rifting to collisional crustal shortening - Paleoproterozoic Kaleva metasediments of the Hoytiainen area in North Karelia, Finland. Geological Survey of Finland, Bulletin 380:79

Kraus MJ (1999) Paleosols in clastic sedimentary rocks: their geologic applications. Earth Sci Rev 47(1-2):41-70

Madukwe HY, Bassey CE (2015) Geochemistry of the Ogwashi-Asaba Formation, Anambra Basin, Nigeria: Implications for provenance, tectonic setting, source area weathering, classification and maturity. Inter J Sci Techno 4(7):312-327

Madukwe HY, Obasi RA, Fakolade OR, Bassey CE (2015) Provenance, tectonic setting and source-area weathering of the coastal plain sediments, South West, Nigeria. Sci Res J (SCIRJ) III(II):20-31

Madukwe HY, Ayodele SO, Akinyemi SA, Adebayo OF (2016) Classification, maturity, provenance, tectonic setting, and sourcearea weathering of Ipole and Erin Ijesa stream sediments, South West Nigeria. International Journal of Advanced Scientific and Technical Research 1(6):232-255

Malaren S, Aljuaidi F, Bateman M, Millington A (2009) First evidence for episodic flooding events in the arid interior of central. Saudi Arabia over the last $60 \mathrm{ka}$ Journal of Quaternary Science 24(2): 198-207 
Moore RM (1992) Tfie Skiddaw Group of Cumbria: early Ordovician Turbidite sedimentation and provenance on an evolving microcontinental margin. Submitted in accordance with the requirements for the degree of Doctor of Philosophy. University of Leeds Department of Earth Sciences, p 300

Moufti MR, Németh K (2016) Geoheritage of volcanic harrats in Saudi Arabia, Geoheritage, Geoparks and Geotourism. Springer International Publishing Switzerland. https://doi.org/10.1007/9783-319-33015-0_2

Nesbitt HW, Young GM (1982) Early Proterozoic climates and plate motions inferred from major element chemistry of lutites. Nature 299:715-717

Nesbitt HW, Young GM (1984) Prediction of some weathering trends of plutonic and volcanic rocks based on thermodynamics and kinetic consideration. Geochim Cosmochim Acta 48:1223-1234

Nesbitt HW, Young GM (1989) Formation and diagenesis of weathering profiles. J Geol 98:801-822

Noori A, Rais S (2014) Geochemistry and detrital models of sandstone from Barakar Formation in Mand Valley Basin, Chhattisgark, India: implications for provenance, tectonic setting and paleo-weathering. Inter J Basic App Sci 14:124-133

Obasi RA, Madukwe HY (2016) Use of geochemistry to study the provenance, tectonic setting, source-area weathering and maturity of Igarra Marble, Southwest, Nigeria. American Journal of Engineering Research (AJER) 5(6):90-99

Pettijohn FJ, Potter PE, Siever R (1987) Sand and sandstone, 2nd edn. Springer, Berlin Heidelberg New York, 553 p

Purser BH, Bosence DW (1998) Sedimentation and tectonics in rift basins - Red Sea - Gulf of Aden. Chapman and Hall London, p 663

Ratcliffe KT, Morton AC, Ritcey DH, Evenchick CA (2007) Whole-rock geochemistry and heavy mineral analysis as petroleum exploration tools in the Bowser and Sustut basins, British Columbia, Canada. Bull Can Petrol Geol 55(4):320-336

Roaldest E (1978) Mineralogical and chemical changes during weathering, transportation and sedimentation in different environments with particular references to the distribution of Ytrium and lanthanide elements. Ph.D. Thesis, Geol. Inst., Univ. of Oslo, Norway

Robin WD (2004) Hominid dispersals and Asian biogeography during the Lower and Early Middle Pleistocene) c. 2.0-0.5 Mya. Asim/ PerspectiJJes, vol. 43(2)

Schmidt D, Hadley D (1984) Middle tertiary continental rift and evolution of the Red Sea in southwestern Saudi Arabia, Saudi Arabian Deputy Ministry for Mineral Resources 56:3-6

Singh A, Paul D, Sinha R, Thomsen JK, Gupta S (2016) Geochemistry of buried river sediments from Ghaggar Plains, NW India: multi-proxy records of variations in provenance, paleoclimate, and paleovegetation patterns in the Late Quaternary. Palaeogeogr Palaeoclimatol Palaeoecol 449:85-100

Smaill J B (2015) Geochemical variations in glauconitic minerals: applications as a potassium fertiliser resource. A Thesis submitted in Partial Fulfilment of the requirement for the degree of Master of Science, University of Canterbury, New Zeeland, p 221

Tabor NJ, Myers TS (2015) Paleosols as indicators of paleoenvironment and paleoclimate. Annu Rev Earth Planet Sci 43(11):1-11

Townsend GN, Gibson R, Horton JW, Reimold WU, Schmitt RT, Bartosova K (2009) Petrographic and geochemical comparisons between the lower crystalline basement-derived section and the granite mega block and amphibolite mega block of the Eyreville B core, Chesapeake Bay impact structure, USA. The Geological Society of America, Special Paper 458:255-275

Wronkiewicz DJ, Condie KC (1987) Geochemistry of Archean shales from the Witwatersrand Supergroup, South Africa Geochim Cosmochim Acta 51:2401-2416

Xu LG, Lehmann B, Mao JW (2012) Mo isotope and trace element patterns of Lower Cambrian black shales in South China: Multiproxy constraints on the paleoenvironment. Chem Geol 318-319: $45-59$ 